\title{
Tertiary level proficiency in ESP: Employer survey analysis
}

\author{
Jana Jašková, Dagmar Št’astná
}

\begin{abstract}
One of the most topical issues in the field of teaching and learning English for Specific Purposes is the question whether tertiary students are able to succeed in mastering English as a foreign language effectively and subsequently to be competitive in the multicultural corporate sphere. The paper presents a study aimed at large employers and their requirements on university graduates' language skills. The research was conducted in November 2018 within 12th JobChallenge Fair in Brno, Czech Republic, where large companies and businesses targeted students as their prospective employees. Following theoretical groundwork, a questionnaire was designed and distributed to representatives of 36 companies operating in engineering, information technology and economy. The aim of the survey was to identify the required language proficiency according to the Common European Framework of References for Languages as a model for describing knowledge levels. Findings show that most of the employers prefer graduates in junior positions with B2 level of English, specifically of both English for General Purposes and English for Specific Purposes. In addition, the analysis reveals a great demand for productive skills such as active participating in meetings, telephoning, business correspondence or presentation skills whereas receptive skills are considered to be less important.
\end{abstract}

Key words: employers' needs; English for Specific Purposes; global multinational companies; language skills; needs analysis; university graduates

\section{Introduction}

Nowadays, English is probably the most frequently taught foreign language at universities, where English for Specific Purposes (ESP) courses should meet the requirements of future employers. With the spread of globalization, ESP has become increasingly important in occupational context and mobility, which requires ESP proficiency. Furthermore, university graduates face high competitive demands within large multinational companies whose main language is English and therefore teaching ESP at universities can contribute to their success at job interviews and further career. Therefore, English teachers at universities should be aware of what global multinational companies require in terms of foreign language. ESP courses are goal oriented and students are supposed to acquire language skills that are demanded in a specific professional environment. This aspect can be seen as a challenge for the ESP teachers, who are trying to identify what their learners' needs are. Rahman (2015) assumes that the ESP curriculum should be designed in cooperation with the learners' professional areas. Some attempts have already been made with the aim to explore the labour market and perform employers' 
needs analyses that can serve as a helpful guideline for developing the ESP curriculum.

In 2010, Charles University in Prague, Faculty of Education, conducted the survey Reflex 2010: graduates' competencies (Zelenka \& Ryška, 2011),which evaluates the inconsistency between the level of competencies required by the labour market and the level provided by tertiary education. Altogether 8,630 questionnaires, which were distributed among graduates in the Czech Republic, were processed and the results of this project report showed a difference of more than $10 \%$. It means that about $11 \%$ of graduates with average or below-average knowledge of a foreign language hold positions in companies where the above-average level of foreign languages skills is required. Almost a quarter of graduates assess their skills in a foreign language, most often in English, as below-average and also 17\% of them assess their ability to work in an intercultural environment as belowaverage.

Further in-depth analysis Study on Foreign Language Proficiency and Employability was carried out by the European Commission in 2016 (Beadle, Humburg, Smith, \& Vale, 2017). This study examines a labour market demand for foreign language proficiency in the EU-28 Member States. Its outcomes prove English to be the most requested language in international trade and the provision of services. Overall multinational enterprises tend to demand the level of oral skills higher than that of written skills and employers prefer applicants with a high or medium level of foreign language proficiency which is logically associated with the job level. They are convinced this enables effective communication within multinational communities and collaboration on international projects.

Following-up the above-mentioned surveys, the aim of the present research was to find out which areas of English knowledge and skills are emphasized by global companies employing university graduates. The small scale survey was specifically designed for the purposes of creating corresponding study materials at the Department of Foreign Languages, Brno University of Technology (BUT), Czech Republic. The department performs teaching at three faculties - Faculty of Electrical Engineering and Communication (FEEC), Faculty of Information Technology (FIT) and Faculty of Business and Management (FBM). For this reason, the research was focused mainly on companies specialised in engineering, information technology and economy whose demand for skilled graduates has given rise to get valuable feedback from these industries.

\section{Theoretical background}

Needs analyses in the field of foreign language education are often conducted casually by the teachers, for example with the help of a placement test for the 
learners or by asking the employers for a list of desired knowledge and skills. Huhta, Vogt, Johnson, and Tulkki (2013) present some of the most common methods used in needs analyses: (a) non-expert intuitions; (b) expert practitioner intuitions; (c) unstructured interviews; (d) structured interviews; (e) surveys and questionnaires; (f) language audits; (g) observation; (h) text-based analysis; (i) diaries, journals and logs. The authors' opinion is that the most effective way to analyse students' and employers' needs is the triangulation of data, a so-called mixed methodology approach.

The above-mentioned approach was used in a research conducted by Neuwirthová (2009), who created a standard of English (level B1) for students and language teachers at two faculties (FEEC, FIT) of Brno University of Technology, Czech Republic. In her mostly quantitative research, the author used semi-structured interviews with language teachers (11) and professional teachers (36) at the faculties followed by semi-structured questionnaires with students (a random selection of 80), language teachers (11) and prospective employers (33). During the preparation of the questionnaire and interview content, the author proceeded from ESP theory and the European criteria for language education stated in the Common European Framework of References for Languages (CEFR). Subsequently, professionally focused communicative language activities were described for individual language skills, which were ranked by the respondents according to their importance as follows: oral interaction, reading with comprehension, individual speech, listening, writing (the least important).

Similarly, Hloušková (2010) also conducted a needs analysis in language teaching for the purpose of a successful career start of university graduates. Based on her research, she innovated the syllabus for subject English for IT (level B1) at the Faculty of Electrical Engineering and Informatics, University of Pardubice, Czech Republic. The research involved four groups of respondents, namely students $(190$ out of 561), academic staff at the faculty (12), IT specialists in companies (17) and officials from government and local administration bodies who kept track of the situation on the job market (6). The instruments used for the investigation were a semi-structured interview (used with the academic staff, IT specialists and officials) and an electronic questionnaire (completed by the students). On the basis of the results, the author stated that the respondents considered English for General Purposes of the same importance as English for Specific Purposes where they mainly emphasized the knowledge of technical terminology. Furthermore, they preferred both oral and written interactions, whereas speaking was the most important language skill for both the IT specialists and the students.

In the professional literature, there is a great deal of research on the English language students' needs analysis. For example, in the Czech Republic, Jašková (2009) analysed students' needs at the College of Business and Hotel Management 
in Brno. In an anonymous questionnaire distributed to 124 students of bachelor's degree programme, she focused, besides other things, on the students' opinions on individual aspects of the English language (speaking, listening, writing, reading, grammar, pronunciation, specific and general vocabulary). The students' views differed according to their level of English (B1, B2), but speaking skills were both the most important and most popular parts of the English language for all of them. In connection with previous findings, Jašková (2011) conducted another questionnaire survey with 73 students of the above mentioned college. The new questionnaire specifically focused on the respective aspects of the English language and aimed to find out which forms of teaching the students preferred in each area. The results of this research confirmed the fact that students considered the ability to speak as a key one, as they preferred communication activities in pairs or small groups within not only speaking and writing but also grammar and vocabulary areas.

Next, in Poland, the results of needs analysis conducted by Dzieciol-Pedich (2014) among students of Economics and Management at the University of Bialystok, revealed some interesting facts connected with Business English courses. Students' responses concerning the type of English indicated that students preferred a combination of English for General Purposes (EGP) and ESP. The majority of the participants, i.e. 121 out of 199, responded that speaking should be the main focus in ESP lessons as they were supposed to work or go for an internship abroad. Speaking skills were followed by a thorough knowledge of vocabulary and reading skills. Issues concerning marketing, working life or doing business in various cultures were found the most interesting according to students' declared expectations about using Business English in their professional lives.

The importance of needs analysis in ESP is being discussed thoroughly by various researchers and a large variety of theories including a wide spectrum of frameworks for analysing and assessing needs have been proposed. Romanowski (2017) lays great stress on both learners' needs and target situation needs of all the participants who are involved in the learning process, which leads to the development of the syllabus for the ESP courses that are based on the findings from these needs analyses. As a result, he proposes the syllabus design which includes precise requirements and reflections of other participants besides those of learners, namely institutions' requirements and instructors' teaching experience.

\section{Research methodology}

A questionnaire method was used for the needs analysis, due to the possibility of reaching a larger number of respondents and generalizing the research results (Huhta et al., 2013). The questionnaire was distributed in November 2018 within the 12th JobChallenge Fair held in Brno, Czech Republic. The fair was attended 
by 120 companies operating worldwide and each company had the opportunity to talk directly to undergraduate and graduate students.

Firstly, multinational companies where English serves as lingua franca and employees are expected to be familiar with it were selected from the list of exhibitors. However, bearing in mind that the small-scale survey would be conducted, it was decided to opt for quota sampling (Soukup \& Kočvarová, 2016) and the sample consisted of 36 international companies from the following fields engineering, information technology and economy. Classification of the companies was made in accordance with JobChallenge journal, which was published for the purposes of the fair with detailed characteristics of each company and their core business. It is obvious from Figure 1 that the research sample was distributed evenly among these three specialisations.

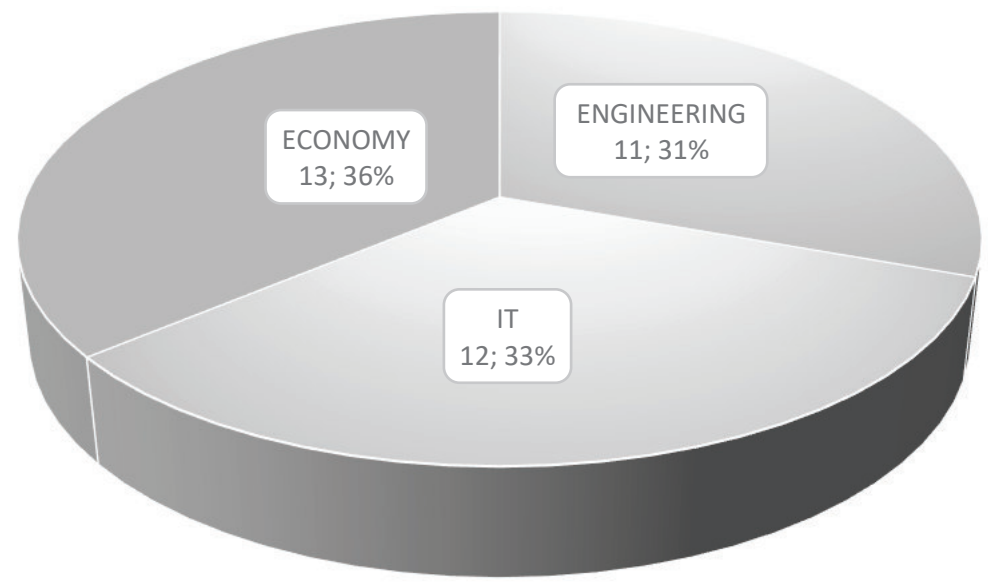

Fig. 1: Companies according to their specialisation

The attention was focused on employers in the field of engineering, information technology and economy because the analysis was conducted for the purposes of three faculties of BUT (FEEC, FIT, FBM). During the small-scale survey, two researchers were orally questioning the exhibitors' opinions, while writing their answers and other notes into the questionnaires.

The questionnaire for the survey (see Appendix) consisted of four parts. In the first part, the respondents informed the researchers about their companies' required language proficiency according to Common European Framework of References for Languages (CEFR), within both English for General Purposes (EGP) and English for Specific Purposes (ESP). The second part of the questionnaire dealt with the required key skills and knowledge, namely reading, writing, speaking, listening, vocabulary, grammar and pronunciation. In the third part, the researchers were interested in other skills required by the businesses. Eight other skills variants - business correspondence, taking part in meetings, managing meetings, negotiating, telephoning, presentation skills, socialising, networking, and intercul- 
tural issues - were offered to the respondents who could add any other skills as well. The last part of the questionnaire was focused on the employers' best practices concerning the use of English in their companies and composed of five questions with a scale of answers. Later, the acquired data was inserted into Excel charts and subsequently, graphs were created according to the results.

\section{Research results}

The most noticeable feature of the presented results is a high priority that was assigned to productive skills by the majority of respondents. These include speaking and writing followed by receptive skills, which include listening and reading. These skills automatically require the necessity of mastering professional vocabulary and lexis. Conversely, grammar proved to be the least preferable component, suggesting that although it is necessary to communicate effectively within the work process it happens regardless of the formal syntactic and grammar rules. The research results show that a proposed ESP course curriculum should reflect the needs of employers and put emphasis on their requirements relating to priority skills. In the following text, the individual parts of the questionnaire are discussed.

\subsection{Required type and level of English}

In connection with the question focused on the required type of English language, most companies preferred students with good knowledge of both English for General Purposes (EGP) and English for Specific Purposes (ESP). On the other hand, a considerable number of firms required graduates' knowledge of EGP and only respondents from several businesses admitted that ESP knowledge is acceptable (Figure 2). Interestingly, Hloušková (2010), as well as Dzieciol-Pedich (2014), also found out that their respondents considered EGP as important as ESP. It seems worth thinking whether a combination of EGP and ESP, with the same attention paid to both elements, would be appropriate for students to learn rather than EGP or ESP separately.

The companies which required EGP knowledge mostly expected at least a B2 level according to the Common European Framework of References for Languages (CEFR), whereas within ESP the required level was at least B1 (Figures 3 and 4). Moreover, other levels for EGP and ESP were also chosen. As for EGP concerns, most of the respondents mentioned B1 and B2 levels sufficient for their businesses. On the contrary, ESP levels acceptable for the employers were wider and covered four levels from A2 up to $\mathrm{C} 1$. The numbers show that the most commonly mentioned levels were B1 and B2, which corresponds to the levels of English subjects at most Czech universities. The required knowledge of foreign languages may also vary markedly depending on the junior or senior position held in the 


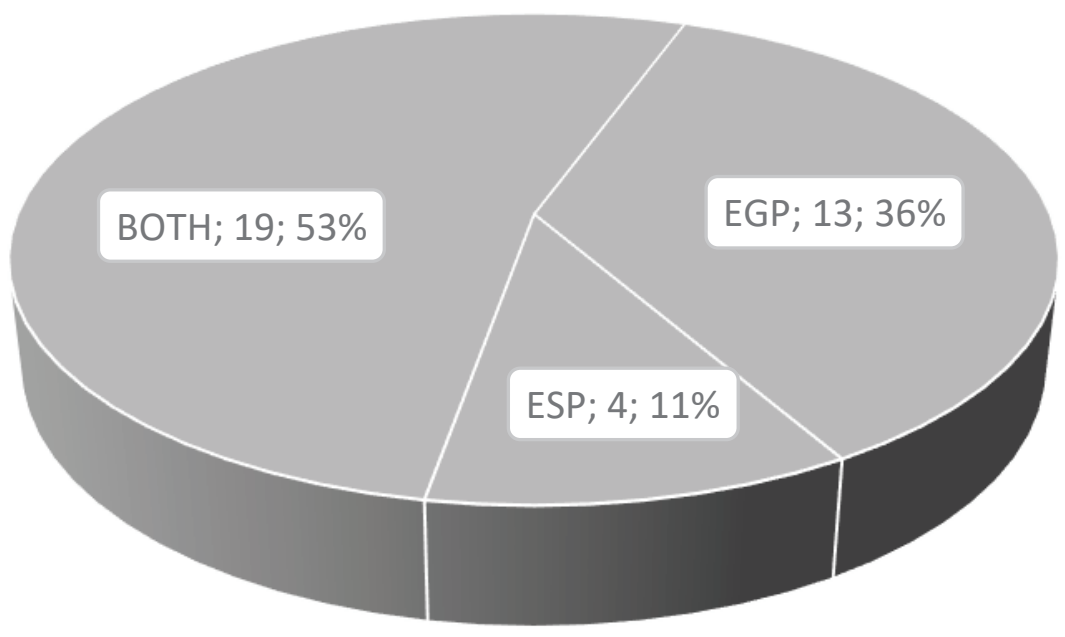

Fig. 2: Required type of English

company. However, since the research focused on graduates and their opportunities on the job market the results concern junior positions only.

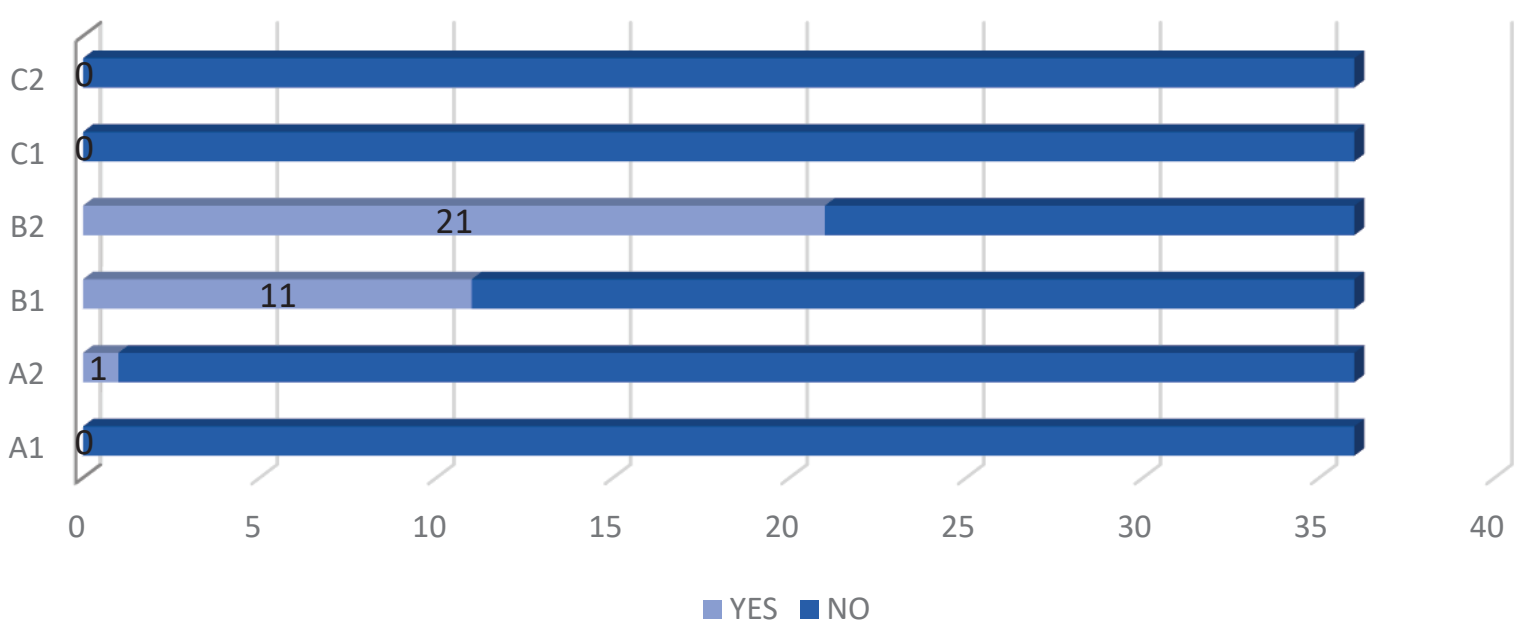

Fig. 3: Required level of EGP

\subsection{Required key and other skills}

In the next part of the questionnaire, the respondents were asked to choose the items which were important for their businesses from a list of key language skills and knowledge. As shown in Figure 5, forthe majority of employers the most demanded area of the English language was speaking followed by writing, reading and listening skills whereas the knowledge of vocabulary, pronunciation and grammar was not so important. To summarise, the productive skills belonged to the most significant aspects that outweighed the other criteria, followed by receptive skills and the knowledge of vocabulary. Grammar and pronunciation were 


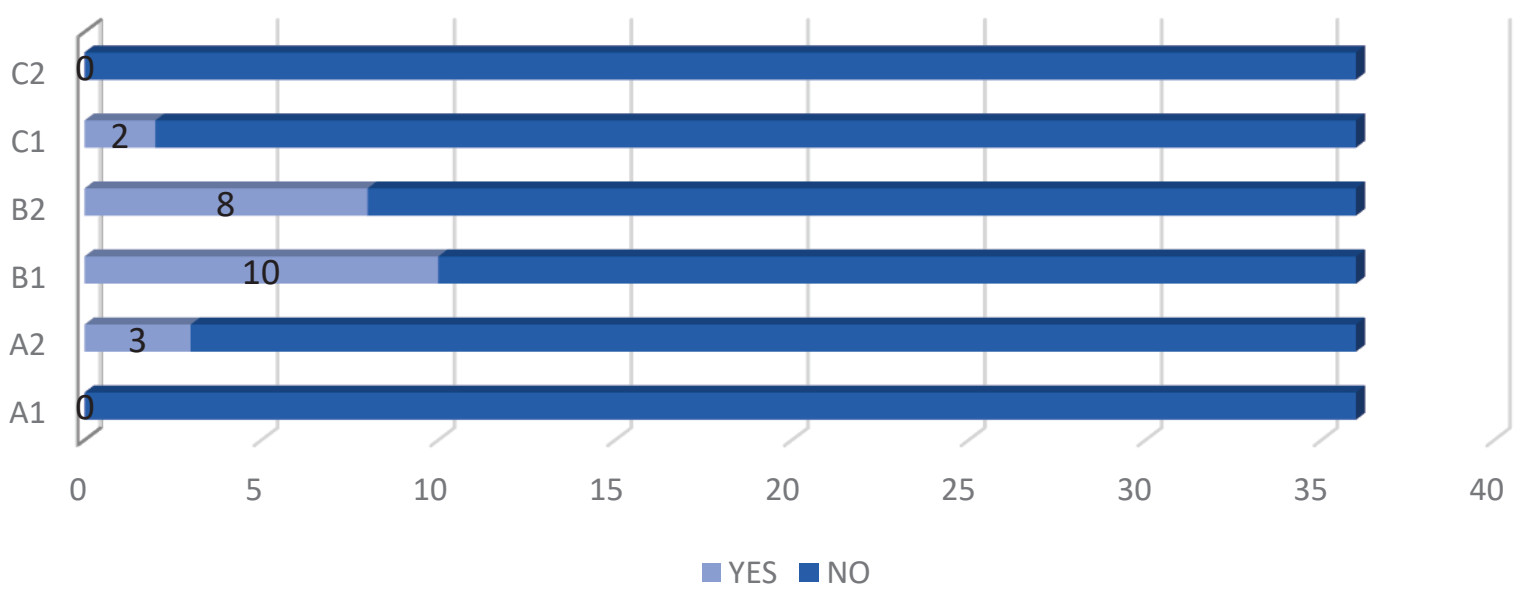

Fig. 4: Required level of ESP

the least demanded skills and therefore it can be assumed that these skills do not represent any serious limitations to job performance. Other authors' research results also reported that the speaking skills were essential not only for employers but also for university students (Dzieciol-Pedich, 2014; Hloušková, 2010; Jašková, 2009, 2011; Neuwirthová, 2009). The results show that the employers need graduates who can verbally express themselves, however, they do not emphasize grammatical accuracy. These results also suggest that it would be very appropriate to devote considerable time to teaching communication skills at universities.

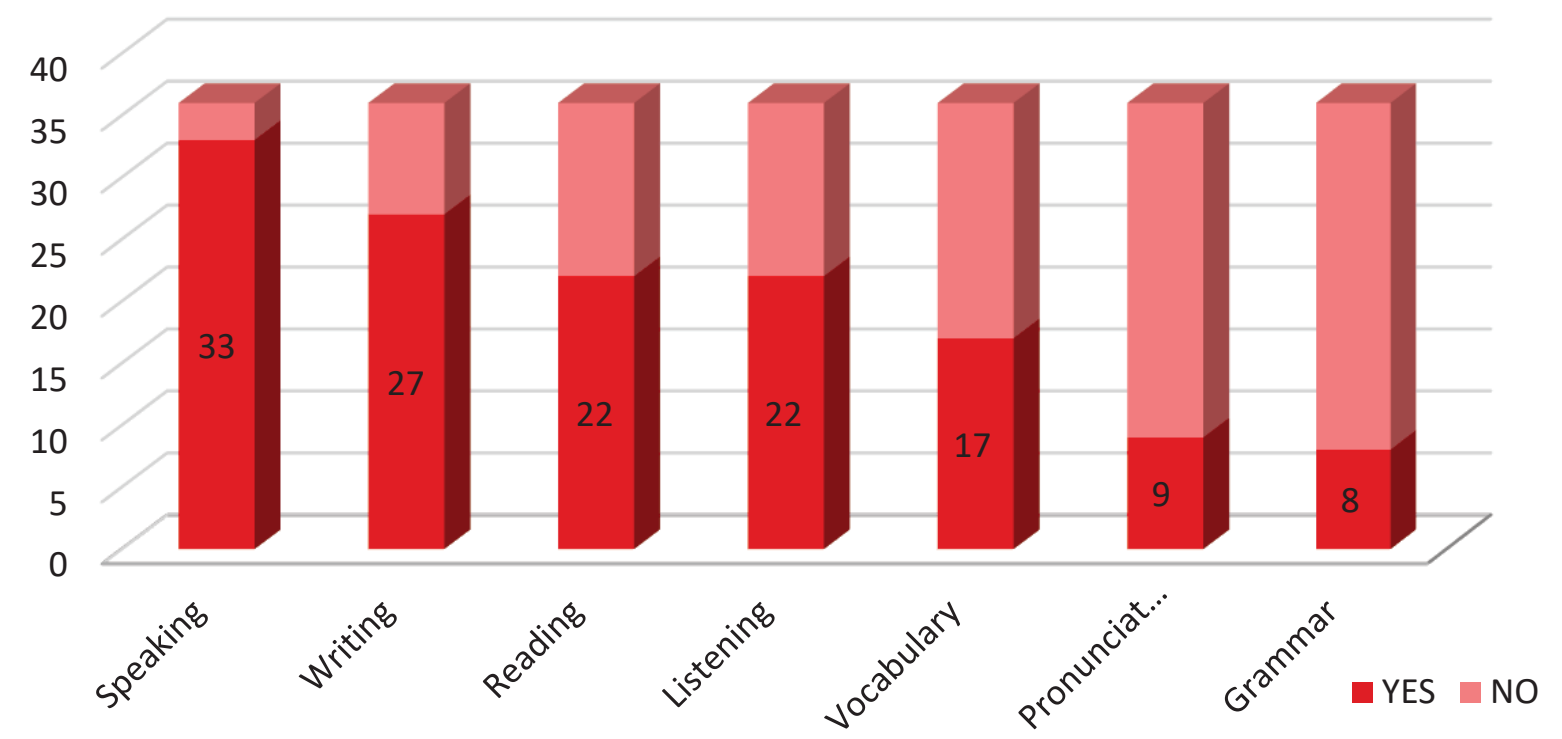

Fig. 5: Required key skills and knowledge

The questionnaire included a list of other required skills that are considered essential in professional life. The employers were asked to select important items 
from the list of other skills and alternatively to add some other skills. Figure 6 represents their responses. They clearly show predominant skills such as taking part in meetings and telephoning followed by business correspondence and presentation skills. Socialising and networking together with negotiating were also of considerable importance whereas managing meetings and cross-cultural issues seemed not to be so crucial for the employers. Their additional explanations showed that the requirement for the last two mentioned skills depended largely on whether the graduate held a junior or senior position in a company. Surprisingly, the knowledge of intercultural issues was commented on that these were mastered by employees directly during the working process. Some of the participants emphasized other skills essential for their business such as writing reports and analyses, understanding written documents, employment contracts, financial statements, or work instructions. To summarise, most of the mentioned skills were very important for future employers and should, therefore, be included in teaching ESP at universities. Moreover, Dzieciol-Pedich (2014) found out that areas like marketing, working life and doing business in various cultures were among the most interesting aspects for students of Business English.

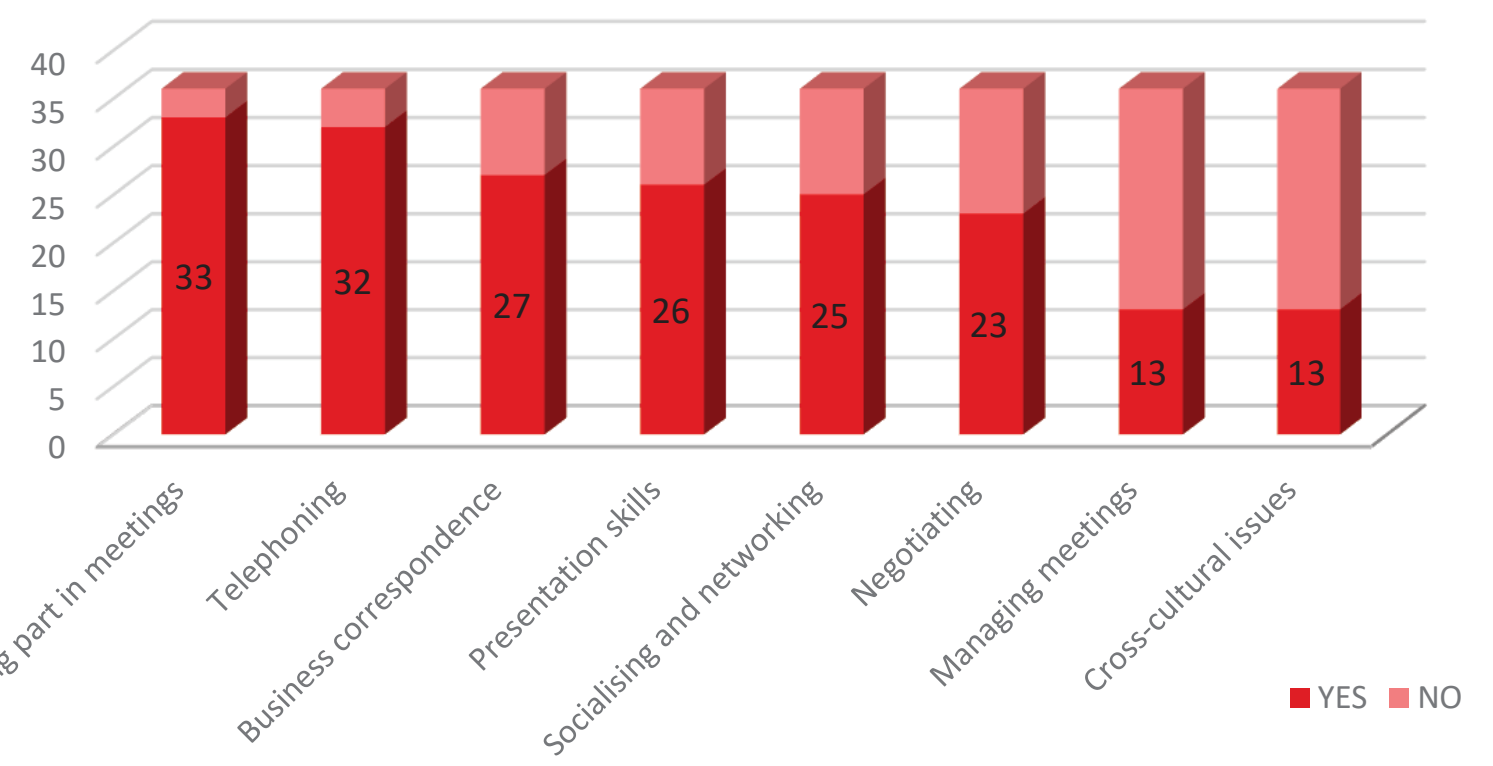

Fig. 6: Other required skills

\subsection{Information on employers}

In the last part of the questionnaire, the respondents were asked five questions concerning their opinions, which were placed on a scale from "yes" to "no" possibilities. Firstly, they stated whether they were satisfied with the language level of the recruited graduates who started working in their companies. Figure 7 shows that most of the respondents expressed their satisfaction with the graduates' knowledge of English. The rest of the respondents favoured "rather no" answer, 
saying that the graduates were lacking in self-confidence in terms of the use of foreign languages, namely spoken language. Although these were the views of a smaller number of respondents, they clearly indicated that teaching English at universities should be improved according to the employers' expectations that graduates should be able to communicate in English in everyday business situations such as taking part in meetings, telephoning, dealing with business correspondence (see Figure 6).

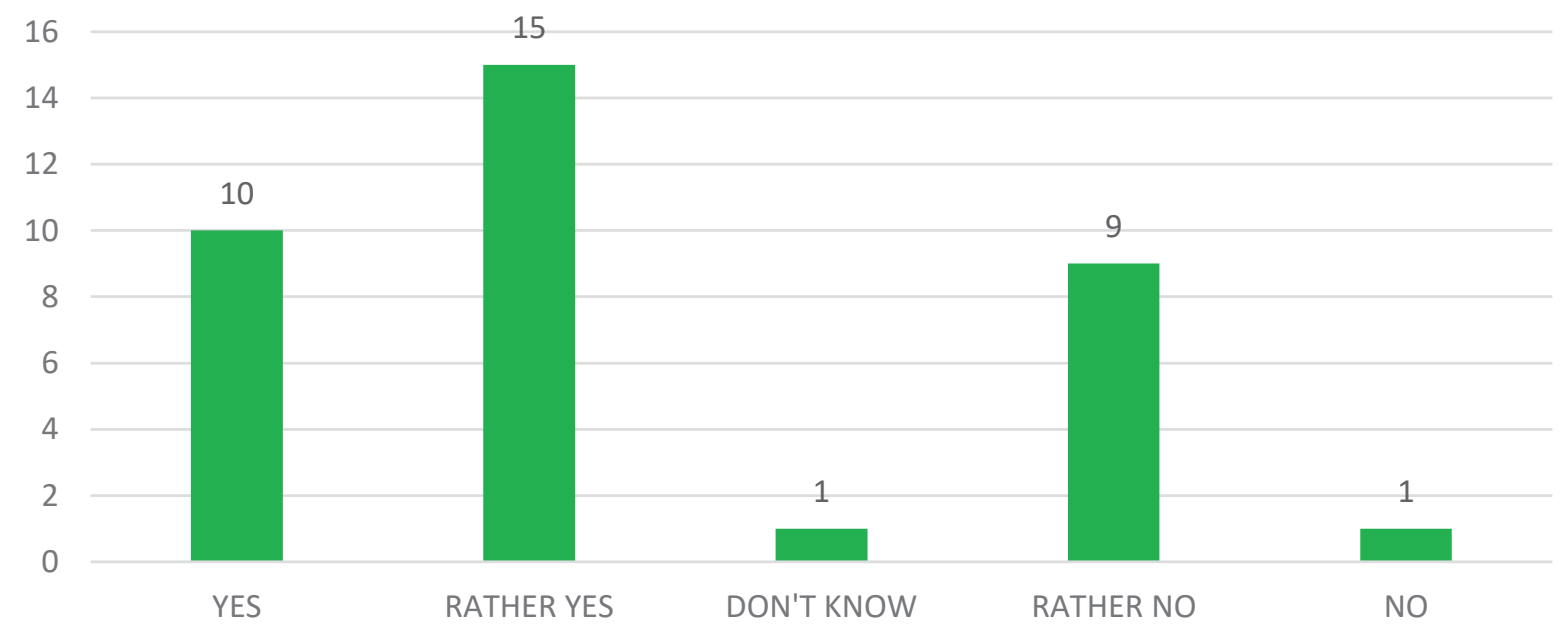

Fig. 7: Satisfaction with the graduates' language level

The second question was focused on whether telephone interviews were parts of the companies' recruitment process to check the English language command of applicants. It is highly visible from Figure 8 that almost half of the businesses used the telephone, or even skype interviews as part of multiple round recruitment processes to verify students' knowledge of English. Therefore, speaking skills should belong to the most preferred aspects of English at universities.

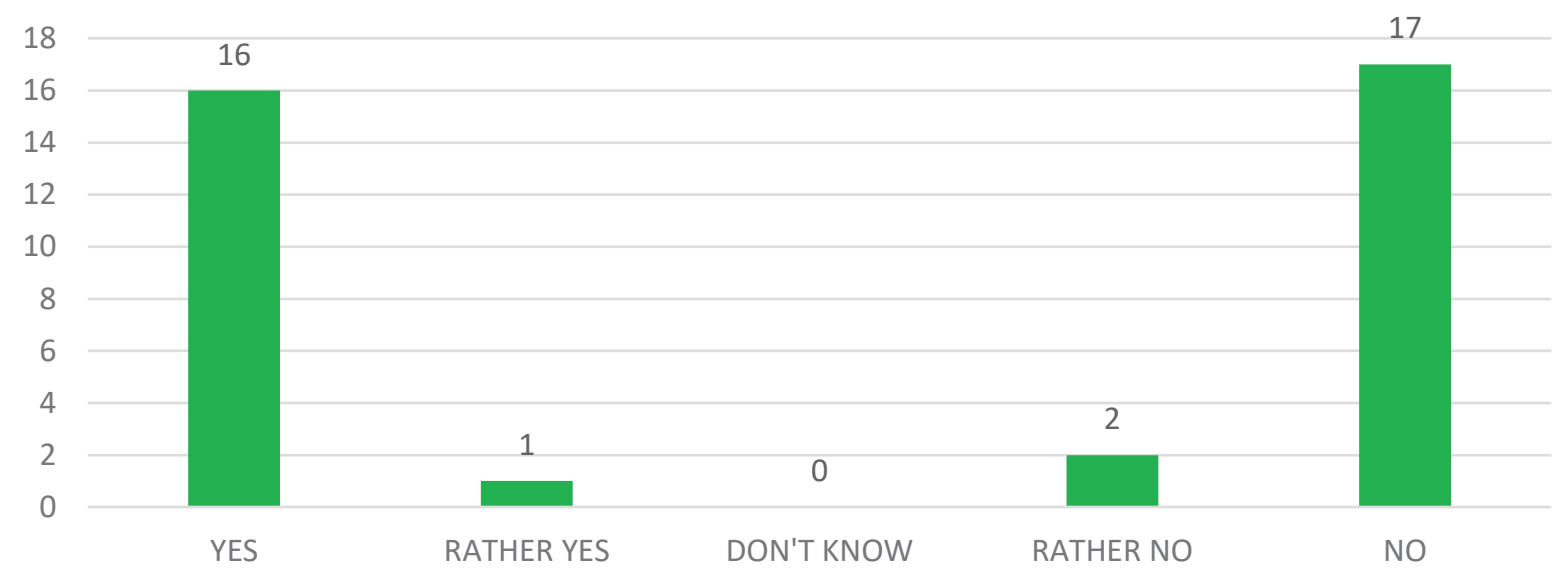

Fig. 8: Telephone interview as part of the recruitment process 
As shown in Figure 9, job interviews in English were conducted by most of the companies interviewed. Job applicants should possess the ability to present themselves well during the job interview, which requires a higher level of language skills, and therefore it may represent a real challenge for applicants. Again, this points to the importance of practising speaking skills within English lessons at universities.

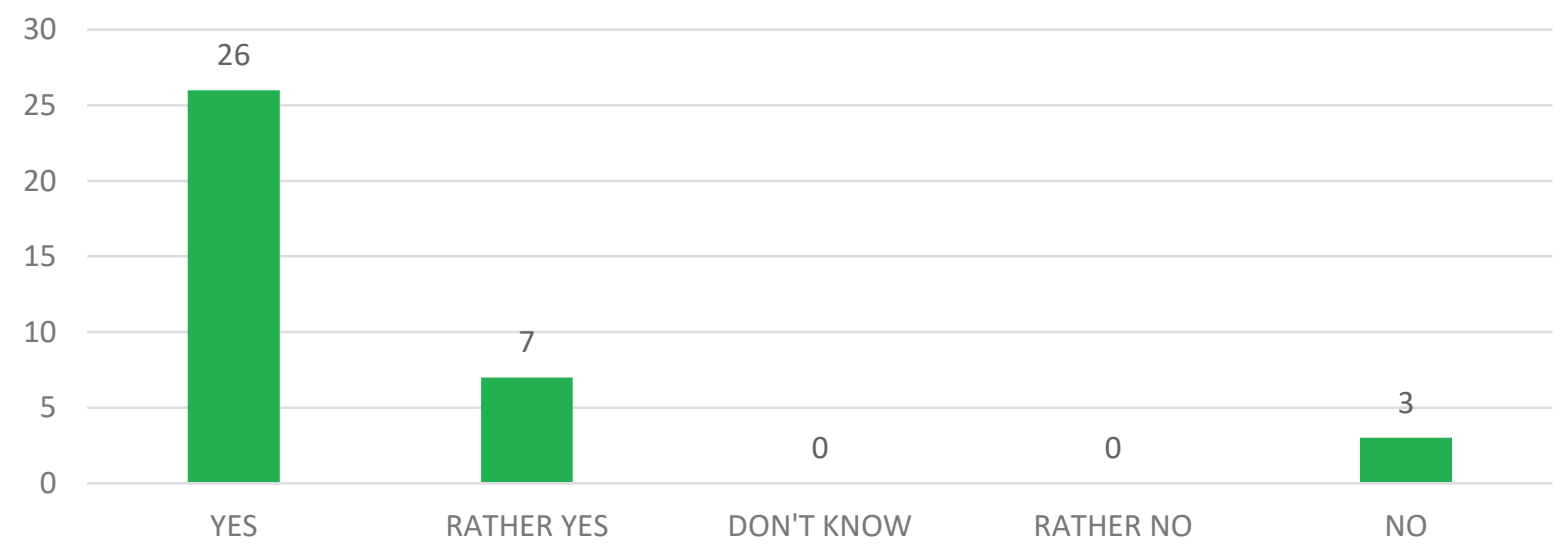

Fig. 9: Job interviews in English

In the fourth question, the employers were asked whether they used entrance tests to verify the language skills of new employees. In Figure 10, the respondents' answers were mostly 'no', which means that the verification of foreign language knowledge took place mostly orally within the job interviews, either by phone calls or face-to-face dialogues. Only a small part of the respondents commented positively stating that it always matters what job position was advertised. This result also suggests that drilling and testing grammar should not be the main focus in teaching English at universities as this should already be mastered by students from previous secondary school language studies.

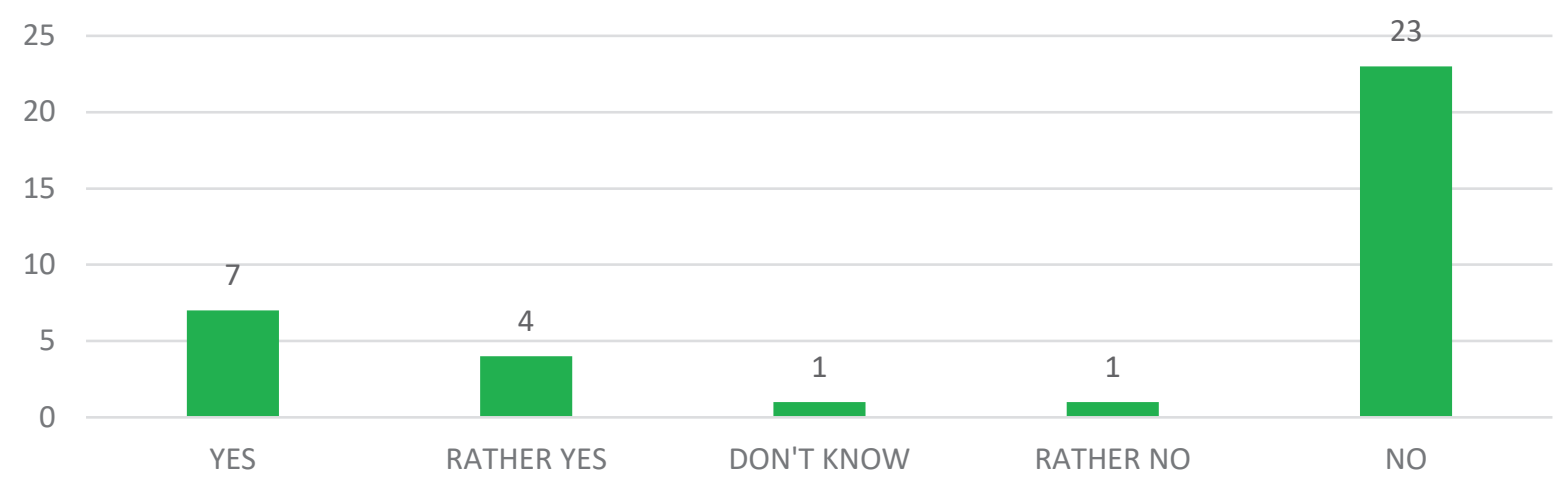

Fig. 10: Entrance tests for verifying language skills 
Finally, the last question concerns the fact of whether companies provided further language training for their employees. Figure 11 shows that almost all companies supported their employees in learning English after finishing their studies at universities. According to their answers, corporate language courses were entirely voluntary and partly paid by employers within specified benefit programmes. This suggests that the companies were willing to support language learning of their prospective employees, but it does not mean that ESP should be downplayed at the expense of other subjects taught at universities.

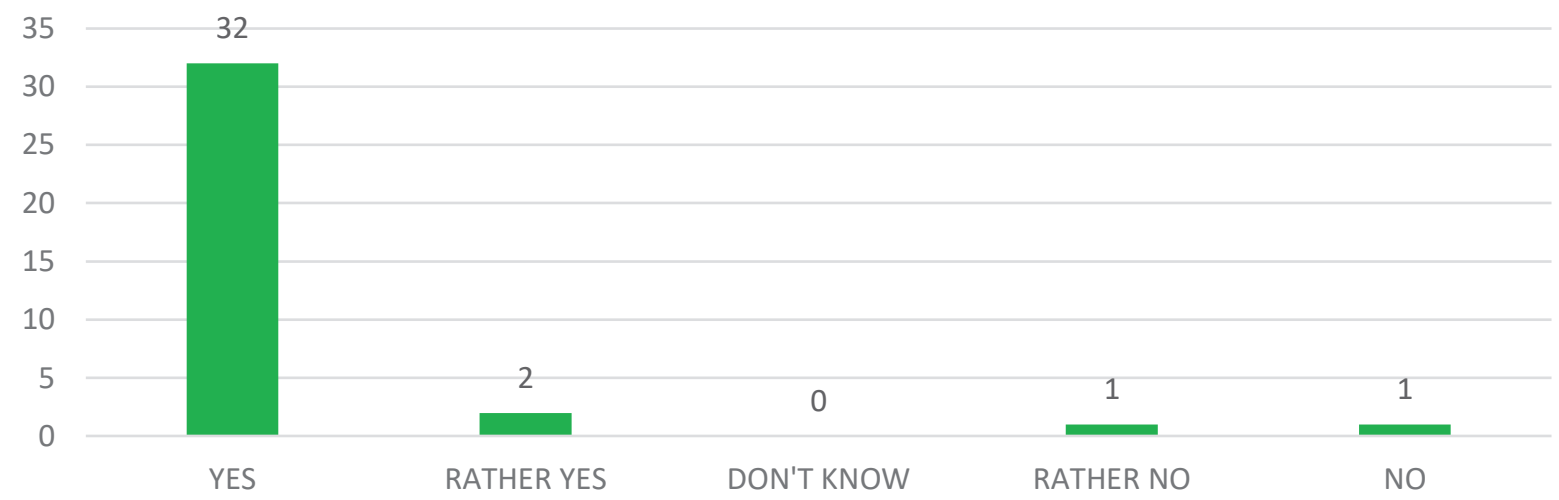

Fig. 11: Providing language training to employees

\section{Discussion}

It is widely known that the amount of the English language lessons at Czech universities is constantly decreasing. The reason is that today's students are getting better prepared from primary and secondary schools, where foreign language teaching is increasingly supported. However, there is also a considerable number of students with insufficient language knowledge coming to universities. These people need to spend a lot of time studying the language at universities to be successful as graduates in the labour market. Moreover, the research results suggest that some companies are not satisfied with university graduates' level of English (see Figure 7). This finding is alarming as it is necessary to take into account that only students with a higher level of English are usually interested in working in international corporations. On the contrary, learners with a lower level of language skills usually seek work in Czech companies or hold lower positions in foreign firms. However, if higher education institutions were more focused on foreign language teaching, these students could also benefit from a greater range of job opportunities both in the Czech Republic and abroad. For the above stated reasons, the importance of foreign language teaching at universities should not be underrated. This is also confirmed by the research findings suggesting that most employers provide continuing language training for their staff (see Figure 11), which means they are not satisfied with their employees' level of English. 
Therefore, English language teaching at universities should be strongly encouraged, which is in accordance with the current trend of English being a necessity and knowledge of other foreign languages is strongly required in the labour market.

It should also be considered whether the employers' expectations are somewhat unrealistic. According to the research results, foreign companies demand especially productive skills, i.e. speaking and writing (see Figure 5). However, if higher education were to focus primarily on these skills, the seminar groups would have to be attended by a much smaller number of students. With a lot of learners in groups, which is a common practice nowadays, students can speak only in pairs or groups, mostly without a direct control of their teachers. Furthermore, correcting essays written by a large number of students would take a disproportionate amount of time for teachers thus increasing their workload. This implies that teaching English at universities should be carried out in smaller groups so that the teacher can devote more attention to individual students, which is currently unrealistic. On the other hand, the results of employers' requirements for their employees' levels of English (see Figures 3 and 4) are much more realistic, as they mostly coincide with the offer of higher education institutions. However, employers would surely welcome even higher levels of university graduates' English.

Based on the research results, the ESP courses should prepare university students to work in a multinational environment of companies and corporations, where English is considered a lingua franca. Taking into account rapidly changing technologies and trends in production, it is essential to create the ESP study materials and course syllabuses that will correspond to these developments. Currently, students prefer to gain information through modern technologies, which represent a great potential in acquiring knowledge and skills in professional English. However, most of the available e-materials focus rather on general English or do not meet the requirements of the university study programmes.

The style of teaching English at universities also seems to be one of the major issues, which has to be taken into account. The high priority for university teachers should be motivating their students to have a good command of a foreign language. Generally, students expect from universities a type of teaching different from that used at primary, secondary or grammar schools. We believe that it is already necessary to adopt the modern approach of teaching instead of schooling in the form of the series of seminars with teacher-centred instructions and textbooks. The ESP courses should be particularly aimed at the efficient use of case studies, project-based learning or task-based learning with the possibility of establishing contacts with specific companies. A strong connection of available technological tools with the ESP content and didactic methods close to practice 
should be formed. In this context, the synergy effect and the link to the needs and objectives of the current education and potential employers may increase.

\section{Conclusion}

In conclusion, the small-scale survey represents a probe that has generated the hypothesis of whether ESP curriculum for universities is in accordance with employers' needs. The research findings show that the results obtained can help university teachers in the area of engineering, IT and economy create effective and useful English courses so that their students could be successful in finding suitable jobs worldwide. These courses should consist of both ESP and EGP because most employers prefer graduates with knowledge of professional as well as general English. Next, the results show that the required level of language skills for junior positions, i.e. positions for fresh graduates, should range somewhere between B1 and B2 according to the CEFR for languages. Within the individual aspects of the English language, productive skills, especially speaking skills, are the most desired by graduates' prospective employers. Therefore, ESP teachers should focus on the practice-oriented course context with the emphasis placed on the combination of productive and receptive skills primarily. Students should be prepared particularly for speaking at meetings, by telephone or during presentations, which suggests the focus on specific professional terminology and lexis. The writing skills were also much required, especially in correspondence, both formal and casual. Moreover, receptive skills, i.e. reading and listening, are ranked high followed by the knowledge of vocabulary. On the other hand, the knowledge of grammar and pronunciation is considered unimportant by employers, so these areas should be marginal within university teaching and given low priority in the ESP courses.

On the whole, the results indicate that some employers do not seem satisfied with graduates' level of English especially in the field of speaking skills, which may act as an incentive for university teachers. New courses and teaching materials tailored exactly to specific students' needs should be created on the basis of further investigation focused on employers' expectations as well as students' or graduates' work experience from their professions. In this way, ESP learning that becomes relevant to real-life professional skills will considerably enhance tertiary students' employability in the labour market and, at the same time, will raise the prestige of teaching English at universities.

\section{References}

Beadle, S., Humburg, M., Smith, R., \& VAle, P. (2017). Study on foreign language proficiency and employability: executive summary. EU publications. Retrieved from https://publications.europa.eu/en/ publication-detail/-/publication/6e68f7e0-dd4a-11e6-ad7c-01aa75ed71a1. 
Dziecol-Pedich, A. (2014). Business English in the eyes of economics and management students at the University of Bialystok. Studies in Logic, Grammar and Rhetoric, 38 (51), 83-102. Retrieved from https://www.academia.edu/22942810/business_english_in_the_eyes_of_economics_and_ management_students_at_the_university_of_bia\%c5\%82ystok

HLoušKové, J. (2010). Analýza potřeb ve vyučování odborného anglického jazyka [Needs analysis in teaching English for Specific Purposes]. (Doctoral dissertation). Faculty of Education, Palacký University Olomouc, Olomouc, Czech Republic. Retrieved from https://theses.cz/id/nzvbjn/ Cela_prace_Hlouskova.pdf

Huhta, M., Vogt, K., Johnson, E., \& TULKKI, H. (2013). Needs analysis for language course design: a holistic approach to ESP. Cambridge: Cambridge University Press.

JAšKovÁ, J. (2009). Anglický jazyk jako prostředek mezinárodního partnerství regionů: výsledky anonymního dotazníku na Vysoké škole obchodní a hotelové v Brně [English language as a means of international partnership of regions: results of an anonymous questionnaire at the College of Business and Hotel Management in Brno]. In K. ViestovÁ \& A. KLAPALovÁ (Eds.), Partnerství v regionu a produkt cestovního ruchu jako výsledek partnerství: sborník př́spěvků z druhé mezinárodní konference (s. 60 to 73). Brno: College of Business and Hotel Management.

JAŠKovÁ, J. (2011). Preference vysokoškolských studentů pro formy výuky obecné angličtiny [University students' preferences in forms of teaching English for General Purposes]. Journal of Tourism, Hospitality and Commerce, 2(1), 12-20.

NeuwiRTHovÁ, L. (2009). Standard cizojazyčného vzdělávání na vysoké škole technického zaměření [Standard of foreign language education at a technical university]. Brno: Akademické nakladatelství CERM.

RAHMAN, M. (2015). English for Specific Purposes (ESP): a holistic review. Universal Journal of Educational Research, 3(1), 24-31. Retrieved from https://eric.ed.gov/?id=EJ1053934

RomANowsKI, P. (2017). Proposing a comprehensive framework for needs analysis in ESP - on the integrality of needs analysis in Business English course design. Glottodidactica 44(2), 147-159. Retrieved from https://www.academia.edu/35096693/Proposing_a_comprehensive_framework_for_needs_ analysis_in_ESP_on_the_integrality_of_needs_analysis_in_Business_English_

SoukuP, P., \& KočVARová, I. (2016). Size and representativeness of research sample in quantitatively oriented educational research. Pedagogická orientace 26(3), 512-536. Retrieved from https://journals.muni.cz/pedor/article/viewFile/6137/5510

ZElenkA, M., \& RYŠKA, R. (2011). Reflex 2010: zpráva čtvrtá: kompetence absolventů [Reflex 2010: the fourth report: graduates' competencies]. Praha: SVP Univerzita Karlova. Retrieved from http://www.strediskovzdelavacipolitiky.info/download/REFLEX2010_Zprava4.pdf

\section{Authors}

Mgr. Jana Jašková, Ph.D., e-mail: jaskovaj@feec.vutbr.cz, Department of Foreign Languages, Faculty of Electrical Engineering and Communication, Brno University of Technology, Czech Republic.

The author graduated from the Faculty of Science and the Faculty of Education, Masaryk University in Brno, Czech Republic, where she received her doctoral degree in Foreign Language Didactics. Her research interests include teachers' professional development, pedagogical content knowledge, and English for Specific Purposes didactics.

Mgr. Bc. Dagmar Štastná, e-mail: dstastna@feec.vutbr.cz, Department of Foreign Languages, Faculty of Electrical Engineering and Communication, Brno University of Technology, Czech Republic.

The author graduated from the Faculty of Philosophy and Science, Silesian University in Opava, and the College of Entrepreneurship and Law in Ostrava, Czech Republic. She focuses on English for Specific Purposes both at bachelor and master levels, specializes in business communication skills and actively participates in designing e-learning courses. 
Appendix: Questionnaire for the survey

FACULTY OF ELECTRICAL department

ENGINEERING of foreign languages

AND COMMUNICATION

Brno University of Technology

Faculty of Electrical Engineering and Communication

Department of Foreign Languages

\section{COMPANY:}

\begin{tabular}{|l|l|}
\hline \multicolumn{2}{|c|}{ Required language proficiency according to CEFR / SERR* } \\
\hline English for General Purposes (EGP) & English for Specific Purposes (ESP) \\
\hline & \\
\hline
\end{tabular}

*Common European Framework of References for Languages / Společný evropský referenční rámec

\begin{tabular}{|c|c|c|c|c|c|c|}
\hline \multicolumn{7}{|c|}{ Required Key Skills and Knowledge } \\
\hline Reading & Writing & Speaking & Listening & Vocabulary & Grammar & Pronunciation \\
\hline & & & & & & \\
& & & & & & \\
\hline
\end{tabular}

Other required skills

Business correspondence

Taking part in meetings

Managing meetings

Negotiating
Telephoning

Presentation skills

Socialising and networking

Cross-cultural issues

Other language skills not listed above:

1. Are you satisfied with the language level of graduates entering your company?
O Yes
O Rather yes
O Don't know
O Rather No
O No

2. Is a telephone interview part of your recruitment process to check the English language command of applicants?
$\mathrm{O}$ Yes
Rather yes
Don't know
O Rather No
No

3. Do you conduct a job interview in English?
O Yes
O Rather yes
O Don't know
O Rather No
O No

4. Do you use entrance tests to verify the language skills of new employees?
O Yes
Rather yes
O Don't know
O Rather No
O No

5. Do you provide language training to your employees?
O Yes
O Rather yes
O Don’t know
O Rather No
No 